\title{
PENGEMBANGAN SISTEM NANOSTRUCTURED LIPID CARRIERS (NLC) MELOXICAM DENGAN LIPID MONOSTEARIN DAN MIGLYOL 808 MENGGUNAKAN METODE EMULSIFIKASI
}

\author{
Rahmi Annisa, Esti Hendradi*, Dewi Melani \\ Departemen Farmasetika Fakultas Farmasi Universitas Airlangga \\ Jln. Dharmawangsa Dalam, Surabaya \\ *e-mail: flowerannisa@gmail.com
}

\begin{abstract}
The aim this study was to determine the effect of Monostearin and Miglyol 808 lipid ratio in NLC system formulation resulting in physicochemical characteristics, release rate, and penetration rate. The NLC making was done by using emulsification method. In the formulation of NLC meloxicam, 3 different lipid ratios were used, including ratios of 6:4, 7:3, 8:2. Meloxicam served as active ingredient, monostearin served as solid lipid, miglyol 808 served as a liquid lipid, and tween 80 was surfactant. NLC meloxicam physicochemical characteristics include tests of organoleptic, $\mathrm{pH}$, viscosity, particle size, particle morphology and entrapment efficiency. NLC meloxicam belongs to semisolid preparations with $\mathrm{pH}$ value range of 5,72-5,87. Increasing viscosity of $N L C$ system are cause by increase of solid lipid. The measurement results of particle size of three different lipid formulas indicated that the lipid particle size was $<1000 \mathrm{~nm}$. Test of NLC particle morphology by using Transmission Electron Microscopy (TEM) indicated the spherical particle shape (round). Entrapment efficiency test of all NLC-lipid compositions revealed quite high result (> 80\%). The determination of release rate (flux) and penetration rate (flux) was conducted by using Franz diffusion cells with a cellophane membrane for the release and Wistar rat's skin membrane for the penetration. The release rate values of three NLC meloxicam formulas showed p value (sig) 0,005, while the penetration rate obtained p value (sig) 0,091.
\end{abstract}

Keywords: NLC, meloxicam, physicochemical characterization, release rate and penetration rate.

\section{PENDAHULUAN}

Meloxicam merupakan golongan Non Steroidal Anti Inflammatory Drugs. Meloxicam dapat digunakan pada terapi rheumathoid arthritis (Bertram \& Katzung, 2009). Namun penggunaan oral meloxicam menimbulkan efek samping iritasi gastrointestinal Penggunaan meloxicam topikal dapat menjadi solusi penghantaran obat golongan NSAID secara langsung menuju target penyakit dan memberikan efek lokal (El-Megrab, et al., 2001). Cara ini juga dapat menghindari munculnya efek samping gastrointestinal karena tidak diabsorbsi secara sistemik. Meloxicam memiliki karakteristik tidak larut dalam air dan memiliki nilai $\log \mathrm{P} 3.42$, sehingga pada sediaan yang sebagian besar komponennya adalah air, kelarutan meloxicam akan sangat kecil dan dengan nilai $\log \mathrm{P}$ tersebut berarti meloxicam lebih bersifat non polar. Oleh karena itu, pada pengembangan sistem penghantaran topikal meloxicam ini, dibuat Nanostructured Lipid Carriers (NLC) 
sebagai pembawa untuk meningkatkan penetrasi meloxicam ke dalam kulit.

Sistem pembawa NLC merupakan generasi baru dari Solid Lipid Nanoparticles (SLN) yang dapat digunakan sebagai pembawa obat untuk penghantaran topikal. NLC merupakan sistem penghantaran obat yang terdiri dari campuran lipid padat dan lipid cair, membentuk matrik inti lipid yang distabilkan oleh surfaktan (Cirri, et al., 2012). Ukuran partikel NLC pada rentang 10-1000 nm (Pardeike, et al., 2009; Souto \& Muller, 2007; Muller, et al., 2002). Ukuran partikel lipid yang kecil dapat meningkatkan penyerapan hingga ke stratum korneum dan dapat meningkatkan laju pelepasan obat yang dapat dikendalikan (Muller, et al., 1998).

$$
\text { NLC sebagai sistem }
$$

penghantaran obat telah menarik banyak perhatian bagi para peneliti (Souto \& Muller, 2007). Sehingga, NLC dapat mengatasi kelemahan yang dimiliki SLN. Kelemahan umum yang diamati pada SLN adalah jumlah muatan obat yang terbatas dan adanya kerusakan obat selama penyimpanan (Westesen, 1997). Dibandingkan dengan SLN, NLC memiliki jumlah muatan obat yang lebih tinggi untuk sejumlah senyawa aktif dan dapat meminimalkan kerusakan senyawa aktif selama penyimpanan (Muller, et al., 2002). Sistem dispersi NLC memiliki viskositas rendah dan nyaman untuk digunakan pada kulit (Souto \& Muller, 2007). Viskositas mempengaruhi mobilitas dan kemudahan pergerakan bahan aktif untuk lepas dari pembawa. Semakin tinggi viskositas sediaan maka akan semakin besar hambatan pelepasan yang berakibat semakin lama waktu difusi bahan aktif, sebaliknya semakin encer sediaan mobilitas molekul bahan aktif akan meningkat sehingga tidak ada hambatan dalam pelepasan (Anggraeni, et al., 2012).

Beberapa penelitian telah menggunakan NLC sebagai sistem penghantaran obat topikal. Flurbiprofen dalam sistem NLC memiliki efektivitas yang tinggi, dan tidak menyebabkan iritasi pada pemakaian topikal (Bhaskar, 2012). Penggunaan lain sistem pembawa NLC dapat diterapkan dalam kosmetik dan produk dermal (Pardeike, et al., 2009). Beberapa contoh bahan aktif obat yang digunakan dalam penerapan NLC antara lain: topical glucocorticoids (Sivaramakrishnan, et al., 2004), anti androgen (Stecova, et al., 2007), dan anti fungal (Souto, et al., 2004), anti inflamasi (Phatak \& Chaudhari, 2013), dan sistem penghantaran obat pelepasan terkontrol dalam sistem NLC untuk meloxicam (Khurana, et al., 2013).

Pembuatan NLC dapat dilakukan dengan beberapa metode antara lain: high shear homogenization and ultrasound, high pressure homogenization, emulsification solven evaporation, dan teknik emulsifikasi (Mehnert, 2001). Teknik emulsifikasi memiliki keuntungan dibandingkan metode pembuatan yang lainnya, metode ini lebih mudah dan dapat memberikan hasil penjebakan yang baik. Penggunaan metode ini dalam pembentukan NLC telah banyak diteliti dengan menggunakan berbagai bahan obat, diantaranya meloxicam (Khurana, 2013), celecoxib (Joshi, 2008), dan progesteron (Yuan, et al., 2007).

Pembuatan NLC dilakukan dengan mencampur lipid padat dalam jumlah yang lebih besar dibandingkan dengan lipid cair. Hasil pencampuran tersebut berupa matriks yang dapat menjebak obat dalam jumlah yang relatif besar. Keuntungan menggunakan lipid sebagai sistem penghantaran topikal berkaitan dengan sifat fisiologis karena dapat mengurangi toksisitas dan iritasi lokal. Beberapa lipid yang berbeda telah digunakan untuk pembuatan NLC, antara lain: monotrigliserida, digliserida, trigliserida termasuk monoacid, dan polyacid acylglycerols (Souto \& Muller, 2007). 
Penelitian untuk mempelajari kombinasi lipid padat dan lipid cair dalam meningkatkan stabilitas, kapasitas penjebakan bahan obat, dan dapat mengontrol pelepasan telah banyak dilakukan. Diantaranya adalah kombinasi Monostearin dan Miglyol 812 dengan perbandingan 6:4 (Hu, et al., 2006). Penelitian tersebut menunjukkan peningkatan stabilitas, kapasitas muatan yang besar dan dapat mengontrol pelepasan obat clobetasol propionat dibandingkan penggunaan Monostearin tanpa Miglyol 812 dalam pembentukan SLN. Selain itu, kombinasi gliseril behenate dan Miglyol 812 dengan bahan obat aciclofenak menggunakan perbandingan 8:2 menunjukkan morfologi partikel yang spheris dengan ukuran partikel $266 \mathrm{~nm}$ dan memiliki efisiensi penjebakan yang tinggi sekitar 99,22\% (Phatak \& Chaundhari, 2013). Penelitian lain dengan menggunakan lipid yang sama dengan perbandingan yang berbeda yaitu 7:3 dengan model obat ketoprofen menunjukkan morfologi partikel spheris dengan ukuran partikel $393 \mathrm{~nm}$ dan memiliki efisiensi penjebakan sekitar 58,40\%. Pada dua perbandingan dengan lipid yang sama tersebut (8:2 dan 7:3) menunjukkan bahwa pada perbandingan 8:2 merupakan perbandingan terbaik dibandingkan dengan 7:3. Penggunaan lipid padat Monostearin memiliki kelebihan dibandingkan dengan penggunaan lipid padat lain seperti gliseril behenate maupun cetyl palmitat. Monostearin memiliki bentuk polimorf yang stabil serta memiliki potensi yang rendah untuk berubah bentuk dari satu bentuk ke bentuk polimorf lain (Souto \& Muller, 2007).

NLC yang baik dapat ditunjukkan dengan melakukan pengujian $\mathrm{pH}$, viskositas, ukuran partikel, morfologi partikel, efisiensi penjebakan obat, pelepasan bahan obat, penetrasi perkutan secara in vitro dan stabilitas fisikokimia. Pengujian penetrasi dilakukan untuk mengetahui efektivitas obat pada target dengan menggunakan model kulit dan akan dihasilkan data fluks yang dapat digunakan untuk memperkirakan obat yang masuk kedalam tubuh (Rathbone, et al., 2003). Untuk uji penetrasi in vitro biasanya digunakan membran dari kulit hewan. Kulit dari binatang pengerat seperti (mencit, tikus, dan marmot) merupakan kulit yang paling sering digunakan untuk studi penetrasi in vitro. Keuntungan yang didapat dari kulit binatang ini antara lain adalah ukurannya yang kecil, penanganannya yang mudah serta harganya yang murah (Godin \& Touitou, 2007; Ozguney, et al., 2006).

Penelitian ini menggunaan lipid padat (Monostearin), lipid cair (Miglyol 808) dengan perbandingan 6:4, 7:3, dan $8 ; 2$, surfaktan (Tween 80) serta menggunakan meloxicam sebagai bahan aktif. Evaluasi yang dilakukan pada penelitian ini meliputi karakteristik fisikokimia, uji pelepasan, dan uji penetrasi perkutan secara in vitro dan uji stabilitas fisikokimia. Uji pelepasan dan penetrasi in vitro dilakukan dengan alat uji penetrasi sel difusi Franz. Sebagai media digunakan larutan dapar fosfat $\mathrm{pH}$ 7,4 pada suhu $32 \pm 0,5^{\circ} \mathrm{C}$ untuk pelepasan dan $37 \pm 0,5^{\circ} \mathrm{C}$ untuk penetrasi. Kadar dari meloxicam akan diukur menggunakan spektrofotometer UV pada panjang gelombang $362 \mathrm{~nm}$.

\section{METODE PENELITIAN}

\section{Bahan Penelitian}

Bahan-bahan yang digunakan dalam penelitian ini bila tidak dinyatakan lain, memiliki kemurnian pharmaceutical grade. Bahan utama yang digunakan dalam penelitian ini adalah meloxicam (Apex Healthcare Limited), Monostearin (Sigma aldrich), Miglyol 808 (Sigma aldrich), Tween 80 (PT Croda), Etanol pro analisa (Merck), dapar fosfat $\mathrm{pH} \mathrm{6,0}$ $\pm 0,05$ dan $\mathrm{pH} 7,4 \pm 0,05$ dibuat dari $\mathrm{KH}_{2} \mathrm{PO}_{4}$ (kalium dihidrogen fosfat) dan 
$\mathrm{NaOH}$ (natrium hidroksida) pro analisa (Merck).

\section{Pembuatan Sistem NLC Meloxicam}

\section{Formula}

Sistem NLC meloxicam dibuat dengan perbandingan lipid yang berbeda untuk menghasilkan berat sebesar 60,0 g dan replikasi dilakukan sebanyak tiga kali. Sistem NLC diharapkan memiliki $\mathrm{pH}$ 4,5-6,5, viskositas 32,5-2499,5 cPs, ukuran partikel 10-1000 nm, morfologi partikel yang spheris, dan efisiensi penjebakan 80-99. Rancangan formula sistem NLC tersaji pada Tabel 1.

\section{Cara Pembuatan Sistem NLC Meloxicam}

Metode yang digunakan dalam penelitian adalah emulsifikasi (emulsification). Sistem NLC meloxicam dibuat dengan cara melelehkan fase lipid (Monostearin dan Miglyol 808) dengan menggunakan perbandingan lipid berbeda $(6: 4,7: 3$, dan 8:2), serta meloxicam pada suhu $65^{\circ} \mathrm{C}$. Pada saat yang sama, larutan surfaktan (Tween-80 dan dapar fosfat $\mathrm{pH} 6,0 \pm 0,05)$ disiapkan dan dipanaskan pada suhu $65^{\circ} \mathrm{C}$. Larutan surfaktan panas kemudian didispersikan ke dalam fase lipid panas menggunakan ultra-turax dengan kecepatan $3400 \mathrm{rpm}$ selama 30 menit. Tahap selanjutnya adalah tahap pendinginan, kemudian diaduk menggunakan magnetic stirrer dengan kecepatan $100 \mathrm{rpm}$ hingga mencapai suhu $25^{\circ} \mathrm{C}$. NLC yang telah jadi ditimbang untuk mengetahui berat akhir NLC (Khurana, et al., 2013; Han, et al., 2008; Yuan, et al., 2007).

Tabel 1 Formula sistem NLC meloxicam

\begin{tabular}{|c|c|c|c|c|c|c|}
\hline \multirow{2}{*}{\multicolumn{2}{|c|}{ Bahan }} & \multirow[b]{2}{*}{ Fungsi } & \multirow{2}{*}{$\begin{array}{c}\text { Range } \\
\text { Konsentrasi } \\
(\%)\end{array}$} & \multicolumn{3}{|c|}{ Konsentrasi $(\%-b / b)$} \\
\hline & & & & Formula I & Formula II & Formula III \\
\hline Meloxicam & & Bahan aktif & & 1 & 1 & 1 \\
\hline Monostearin & & Lipid padat & $6^{*}$ & 6 & 7 & 8 \\
\hline Miglyol 808 & & Lipid cair & $3-4^{*}$ & 4 & 3 & 2 \\
\hline Tween 80 & & Surfaktan & $1-15^{* *}$ & 5 & 5 & 5 \\
\hline \multicolumn{4}{|c|}{ Dapar fosfat $\mathrm{pH} 6 \pm 0,05$} & \multicolumn{3}{|l|}{ Sampai 100} \\
\hline \multicolumn{6}{|c|}{ * : Han, et al., 2008} & ** : Rowe, et al., 2009 \\
\hline \multicolumn{7}{|l|}{ Keterangan } \\
\hline Formula I & \multicolumn{6}{|c|}{$\begin{array}{l}\text { : Sistem NLC meloxicam dengan perbandingan lipid Monostearin dan } \\
\text { Miglyol 808 6:4 (formula 1) }\end{array}$} \\
\hline Formula II & \multicolumn{3}{|c|}{$\begin{array}{l}\text { : Sistem NLC meloxicam dengan } \mathrm{p} \\
\text { Miglyol 808 7:3 (formula 2) }\end{array}$} & rbandingan & \multicolumn{2}{|c|}{ d Monostearin dan } \\
\hline Formula III & \multicolumn{6}{|c|}{$\begin{array}{l}\text { Sistem NLC meloxicam dengan } \mathrm{p} \\
\text { Miglyol 808 8:2 (formula } 3 \text { ) }\end{array}$} \\
\hline
\end{tabular}




\section{Evaluasi Karakteristik Fisikokimia Sistem NLC Meloxicam}

\section{Pengukuran pH}

Pengukuran $\mathrm{pH}$ masing-masing formula dilakukan dengan menggunakan $\mathrm{pH}$ meter. Diambil $10 \mathrm{~mL}$ sistem NLC meloxicam, kemudian elektroda dimasukkan kedalam sistem NLC meloxicam lalu dicatat angka yang ditunjukkan $\mathrm{pH}$ meter.

\section{Pengukuran Viskositas}

\section{Pengukuran}

viskositas

menggunakan viskosimeter cone and plate. Plate stasioner membentuk bagian bawah cangkir sampel yang dapat dipindahkan, dan diisi dengan 0,5 mL-2,0 $\mathrm{mL}$ sistem NLC meloxicam. Sampel NLC diletakkan pada sample cup, sampel dipastikan bebas gelembung dan tersebar merata pada permukaan cup. Selanjutnya sample cup dipasangkan kembali pada viscometer, viscometer dinyalakan, lalu dibiarkan beberapa saat sampai pembacaan stabil.

\section{Pengukuran Ukuran Partikel NLC}

Pengukuran ukuran partikel ratarata dan distribusi ukuran partikel sistem NLC meloxicam dilakukan dengan menggunakan Delsa ${ }^{\mathrm{TM}}$ Nano. Ditimbang 1,0 g sistem NLC, ditambahkan aquades hingga volume $10 \mathrm{~mL}$, kemudian dimasukkan ke dalam kuvet. Kuvet yang digunakan harus bersih dari busa dan lemak. Kuvet yang telah diisi sampel dimasukkan ke dalam sample holder. Alat dinyalakan dan dipilih menu particle size. Alat akan mengukur sampel selama 10 menit. Data yang dihasilkan merupakan ukuran partikel yang dihitung dari fluktuasi rata-rata intensitas hamburan cahaya.

\section{Pemeriksaan Morfologi Partikel Sistem NLC Meloxicam}

Morfologi partikel dilakukan dengan Transmission Electron Microscope (TEM), pemeriksaan ini dilakukan dengan tujuan untuk mengetahui bentuk partikel yang terdapat dalam NLC. Tiga tetes NLC meloxicam ditempatkan ke dalam kisi tembaga yang dilapisi karbon yang telah dikeringkan dahulu sebelumnya pada suhu kamar, dilakukan pada voltase 120 KVA. Perbesaran yang digunakan adalah 500x.

\section{Pengukuran Persen $\quad$ Efisiensi Penjebakan}

Ditimbang 1 g NLC, kemudian ditambahkan dengan dapar fosfat $\mathrm{pH} 7,4$ $\pm 0,05$ hingga volume $10 \mathrm{~mL}$. Pengukuran persen efisiensi penjebakan dilakukan dengan menggunakan spektrofotometri UV. Hasil pemisahan berupa meloxicam yang terjebak dalam sistem NLC akan mengendap setelah dipisahkan dengan sentrifus pada 2500 rpm selama 45 menit. Meloxicam yang tidak terjebak dalam sistem NLC akan terdispersi dalam dapar fosfat $\mathrm{pH}$ 7,4 \pm 0,05 sebagai supernatan. Selanjutnya dilakukan pengukuran konsentrasi obat bebas pada fase air pada dispersi NLC. Blanko yang digunakan ialah sistem NLC tanpa penambahan meloxicam dan dipreparasi sesuai sampel uji. Selanjutnya dihitung dengan menggunakan rumus:

$\mathrm{EE}(\%)=[(\mathrm{Ct}-\mathrm{Cf}) / \mathrm{Ct}] \times 100 \%$

Keterangan :

$\mathrm{Ct}$ : Jumlah bahan obat yang digunakan

Cf : Jumlah bahan obat yang berada pada fase air

\section{Pengujian Pelepasan dan Penetrasi Meloxicam dalam Sistem NLC}

Membran pelepasan yang digunakan dalam uji pelepasan meloxicam dari sistem NLC ini adalah membran selofan. Membran Penetrasi Tikus dari galur Wistar jantan. 


\section{Pengukuran Meloxicam yang Terlepas dan Terpenetrasi dari Sistem NLC \\ Pengujian \\ dilakukan \\ menggunakan sel difusi Franz.}

Kompartemen cairan reseptor pada alat sel difusi Franz diisi dengan larutan

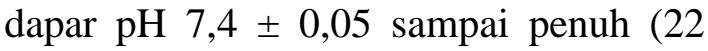
$\mathrm{mL}$ ). Sebanyak $1,0 \mathrm{~g}$ sistem NLC meloxicam diletakkan pada permukaan membran kulit tikus pada alat sel difusi Franz. Stirrer dimasukkan ke dalam sel difusi Franz. Sel difusi Franz kemudian diletakkan pada bejana berisi air yang dilengkapi dengan termometer. Pengambilan sampel disamakan untuk setiap pengujian. Cuplikan diamati serapannya menggunakan spektrofotometer UV.

\section{HASIL DAN PEMBAHASAN}

Tabel 2. Hasil Pengukuran $\mathrm{pH}$

\begin{tabular}{ccccc}
\hline \multirow{2}{*}{ Formula } & \multicolumn{3}{c}{$\mathrm{pH}$} & \multirow{2}{*}{ Rerata \pm SD } \\
\cline { 2 - 4 } & Replikasi I & Replikasi II & Replikasi III & \\
\hline $1(6: 4)$ & 5,73 & 5,71 & 5,71 & $5,72 \pm 0,01$ \\
$2(7: 3)$ & 5,70 & 5,76 & 5,73 & $5,73 \pm 0,03$ \\
$3(8: 2)$ & 5,75 & 5,77 & 5,74 & $5,75 \pm 0,01$ \\
\hline
\end{tabular}

Tabel 3. Hasil pengukuran viskositas sistem NLC meloxicam

\begin{tabular}{ccccc}
\hline \multirow{2}{*}{ Formula } & \multicolumn{3}{c}{ Viskositas (cPs) } & \multirow{2}{*}{ Rerata \pm SD } \\
\cline { 2 - 4 } & Replikasi I & Replikasi II & Replikasi III & \\
\hline $1(6: 4)$ & 31,2 & 33,2 & 31,7 & $32,0 \pm 1,0$ \\
$2(7: 3)$ & 52,1 & 50,3 & 55,5 & $52,6 \pm 5,0$ \\
$3(8: 2)$ & 128,0 & 118,4 & 124,8 & $123,7 \pm 4,9$ \\
\hline
\end{tabular}

\section{Pengukuran pH}

Pengukuran $\mathrm{pH}$ dilakukan dengan menggunakan $\mathrm{pH}$ meter. Hasil pengukuran $\mathrm{pH}$ ketiga formula menghasilkan $\mathrm{pH}$ dalam rentang 5,725,87. $\mathrm{pH}$ NLC meloxicam ini masuk dalam rentang $\mathrm{pH}$ kulit yaitu sebesar 4,56,5. Berdasarkan hasil analisa statistika ANOVA one way pada pengujian $\mathrm{pH}$ NLC meloxicam, diperoleh nilai $\mathrm{p}$ value (sig) sebesar 0,167 lebih besar dari pada $\mathrm{p}$ tabel $(0,05)$. Hal ini menunjukkan bahwa tidak ada perbedaan bermakna antara $\mathrm{pH}$ sistem NLC formula 1, formula 2, dan formula 3 .

\section{Viskositas}

Pengukuran viskositas dilakukan dengan menggunakan viskosimeter Cone and Plate. Viskositas menunjukkan karakteristik suatu cairan. Viskositas adalah tahanan suatu cairan untuk mengalir. Semakin tinggi viskositas suatu sediaan maka semakin tinggi tahanannya (Sinko, 2011). Viskositas NLC dipengaruhi oleh konsentrasi penyusun NLC (lipid padat dan lipid cair). Semakin tinggi konsentrasi lipid padat (Monostearin) dalam formula, maka viskositas NLC semakin meningkat.

Hasil viskositas dari NLC menunjukkan bahwa formula 1 (6:4) memiliki viskositas lebih rendah dibandingkan formula 2 (7:3) dan formula 3 (8:2). Hal ini membuktikan bahwa dengan adanya jumlah lipid padat yang lebih besar dibandingkan lipid cair dalam pembentukan NLC mampu meningkatkan viskositasnya (Muller, et 
al., 2002). Peningkatan Miglyol 808 menurunkan konsistensi NLC meloxicam dan peningkatan konsistensi ini sejalan dengan meningkatnya jumlah Monostearin yang ditambahkan.

Berdasarkan hasil analisa statistika ANOVA one way pada pengujian viskositas NLC meloxicam, diperoleh nilai p value (sig) sebesar 0,000 lebih kecil dari pada $\mathrm{p}$ tabel $(0,05)$. Hal ini menunjukkan bahwa ada perbedaan bermakna antara viskositas formula 1, formula 2, dan formula 3. Untuk mengetahui formula mana yang berbeda maka analisis dilanjutkan dengan uji perbandingan berganda menggunakan analisis Benferroni. Uji perbandingan menghasilkan $\mathrm{p}$ value lebih kecil dari $\alpha=0,05$ pada perbandingan formula 1 (6:4), formula $2(7: 3)$, formula $3(8: 2)$, sehingga dapat disimpulkan bahwa terdapat perbedaan viskositas antara formula 1 dan formula 2, formula 1 dan formula 3, serta formula 2 dan formula 3. Peningkatan viskositas seiring dengan jumlah lipid padat yang digunakan, semakin tinggi jumlah lipid padat (Monostearin) dalam formula, maka viskositas NLC semakin meningkat.

\section{Ukuran Partikel}

Tabel 4. Hasil pengukuran ukuran partikel sistem NLC meloxicam

\begin{tabular}{cccc}
\hline Formula & Replikasi & Ukuran Partikel $(\mathrm{nm})$ & Rerata \pm SD \\
\hline $1(6: 4)$ & I & 845,2 & $518,9 \pm 291,3$ \\
& II & 284,8 & \\
$2(7: 3)$ & III & 426,7 & $472,1 \pm 107,1$ \\
& I & 339,9 & \\
& II & 474,2 & $421,9 \pm 137,1$ \\
& III & 602,2 & \\
& I & 341,7 & \\
& II & 614,9 & \\
& III & 309,1 &
\end{tabular}

Pengukuran ukuran partikel dilakukan dengan menggunakan Delsa ${ }^{\mathrm{TM}}$ Nano. Prinsip kerja Delsa ${ }^{\mathrm{TM}}$ Nano yaitu dengan pemendaran cahaya. Ukuran partikel merupakan karakteristik NLC yang penting karena menentukan homogenitas sistem NLC yang terbentuk, mempengaruhi penjebakan obat, pelepasan obat, penetrasi obat, dan kestabilan sistem NLC.

Dari data yang ada diketahui bahwa ukuran partikel NLC yang paling kecil adalah 421,9 \pm 137,1 dan ukuran yang paling seragam yang ditunjukkan dari harga polidispersiti indexnya yaitu 0,469 . Monostearin memiliki sifat kosurfaktan (Rowe, 2009) dengan adanya monostearin didalam formula akan menurunkan tegangan permukaan antara matriks lipid dan fase air yang berakibat menurunnya ukuran partikel dari NLC. Ukuran partikel NLC yang kecil, menyebabkan kontak antara bahan obat dan membran lebih besar sehingga penetrasi lebih cepat.

Ketiga perbandingan lipid (6:4, $7: 3$, dan 8:2) yang digunakan menghasilkan ukuran partikel < $1000 \mathrm{~nm}$. Berdasarkan hasil analisa statistika ANOVA one way pada pengukuran ukuran partikel, diperoleh nilai $\mathrm{p}$ value (sig) sebesar 0,854 lebih besar dari pada $\mathrm{p}$ tabel $(0,05)$, sedangkan pada pengukuran PI, diperoleh nilai $\mathrm{p}$ value 
(sig) sebesar 0,099 lebih besar dari pada $p$ tabel $(0,05)$. Hal ini menunjukkan bahwa tidak ada perbedaan bermakna antara ukuran partikel dan polidispersiti index formula $1(6: 4)$, formula 2 (7:3), dan formula $3(8: 2)$.

\section{Morfologi Partikel}

Pemeriksaan morfologi partikel NLC dilakukan dengan alat TEM JEOL JEM-1400. Gambaran morfologi NLC meloxicam dapat dilihat pada Gambar.1. Pada hasil pengamatan menggunakan perbesaran 500× menunjukkan morfologi partikel pada sistem NLC formula 1, formula 2, dan formula 3 nampak memiliki bentuk partikel bulat (sferis) dengan ukuran yang masih memenuhi karakteristik NLC.

Pemeriksaan morfologi partikel NLC dilakukan dengan alat TEM JEOL JEM-1400. Gambaran morfologi NLC meloxicam dapat dilihat pada Gambar 1 dan NLC non meloxicam dapat dilihat pada Gambar 2. Pada hasil pengamatan menggunakan perbesaran 500x menunjukkan morfologi partikel pada sistem NLC formula 1, formula 2, dan formula 3 nampak memiliki bentuk partikel bulat (sferis) dengan ukuran yang masih memenuhi karakteristik NLC.
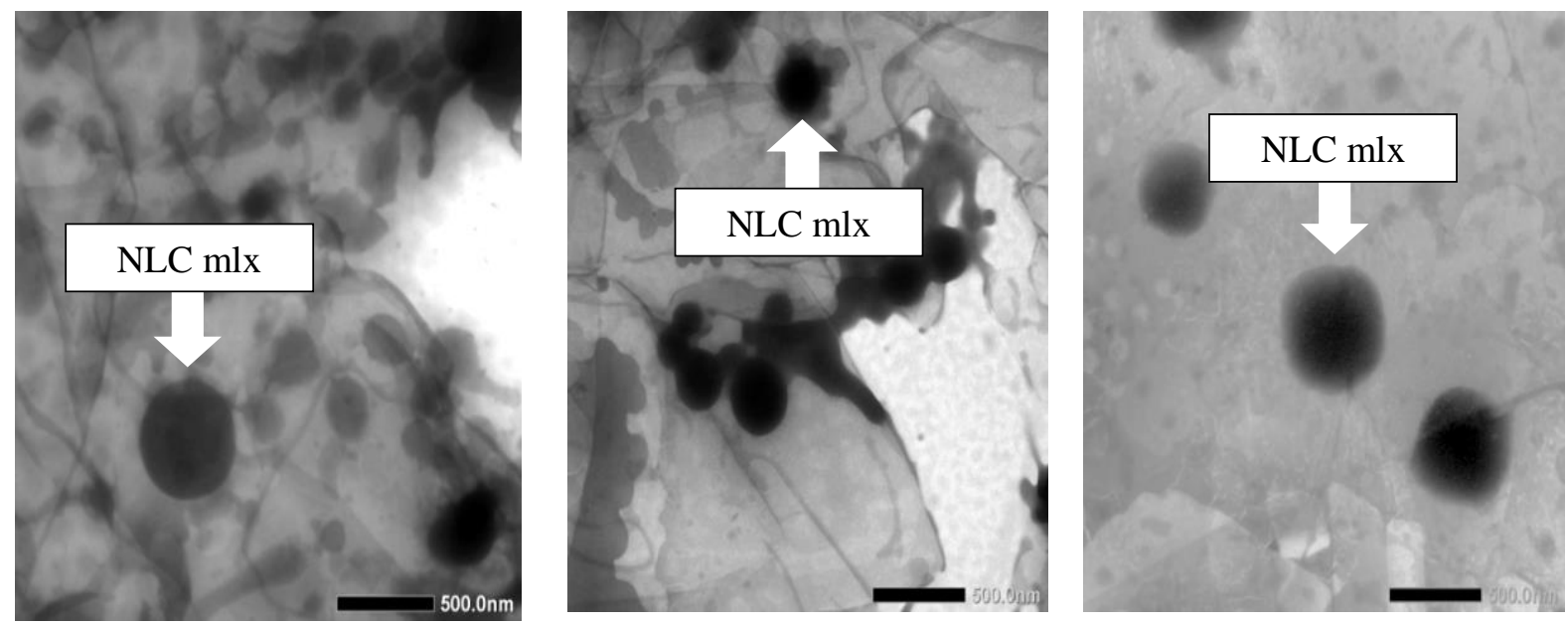

Gambar 1. Morfologi partikel sistem NLC meloxicam dengan menggunakan TEM pada perbesaran $500 \times \mathrm{A}$ : formula 1 (6:4), B: formula 2 (7:3), dan C: formula $(8: 2)$

Tabel 5. Hasil pengukuran efisiensi penjebakan sistem NLC meloxicam

\begin{tabular}{ccccc}
\hline \multirow{2}{*}{ Formula } & \multicolumn{3}{c}{ Penjebakan (\%) } & \multirow{2}{*}{ Rerata \pm SD } \\
\cline { 2 - 4 } & Replikasi I & Replikasi II & Replikasi III & \\
\hline $1(6: 4)$ & 86,623 & 86,732 & 87,710 & $87,022 \pm 0,299$ \\
$2(7: 3)$ & 90,644 & 91,003 & 90,847 & $90,831 \pm 0,180$ \\
$3(8: 2)$ & 94,235 & 94,399 & 94,441 & $94,358 \pm 0,109$ \\
\hline
\end{tabular}

\section{Efisiensi Penjebakan (\%)}

Pengukuran persen efisiensi penjebakan dilakukan dengan menggunakan spektrofotometri UV. Efisiensi penjebakan merupakan langkah yang digunakan untuk mengetahui seberapa besar presentase zat aktif yang terjebak didalam sistem NLC. Dari hasil penentuan \% EP dapat diketahui bahwa 
pada perbandingan lipid penyusun NLC semuanya memberikan hasil penjebakan yang cukup tinggi (>80\%). NLC meloxicam yang dibuat dengan kombinasi lipid monostearin-Miglyol 808 dengan perbandingan 8:2 mampu menjebak meloxicam yang paling tinggi. Campuran antara trigliserida, digliserida dan rantai asam jenuh dapat menghasilkan rantai lipid yang berbeda dari bentuk aslinya. Rantai lipid yang berbeda tersebut dapat memberikan bentuk kristal yang kurang sempurna, sehingga menghasilkan ruang didalam kristal yang lebih besar. Ruang kristal yang membesar tersebut dapat mengakomodasi obat lebih besar sehingga efisiensi penjebakan yang dihasilkan semakin besar (Souto \& Muller, 2007). Semakin besar jumlah meloxicam yang terjebak dalam lipid (pembawa), semakin cepat penetrasinya karena semakin besar gradien konsentrasi yang mendorong terjadinya proses difusi pasif dalam penetrasi. Pada formula 3
(8:2) jumlah meloxicam yang terjebak dalam sistem NLC lebih besar daripada formula 2 dan 3.

Berdasarkan hasil analisa statistika ANOVA one way pengujian efisiensi penjebakan meloxicam dalam sistem NLC, diperoleh nilai $\mathrm{p}$ value (sig) efisiensi sebesar 0,000 lebih kecil dari pada $\mathrm{p}$ tabel $(0,05)$. Hal ini menunjukkan bahwa ada perbedaan bermakna antara efisiensi penjebakan meloxicam pada formula 1 (6:4), formula 2 (7:3), dan formula 3 (8:2). Untuk mengetahui formula mana yang berbeda maka analisis dilanjutkan dengan uji perbandingan berganda. Pada SPSS menggunakan Post Hoc Multiple Compararisons. Uji perbandingan menghasilkan $\mathrm{p}$ value lebih kecil dari $\alpha=0,05$ pada semua perbandingan formula, sehingga dapat disimpulkan bahwa terdapat perbedaan efisiensi penjebakan antara formula 1 dan formula 2 , formula 1 dan formula 3 , serta formula 2 dan formula 3.

\section{Pengujian Pelepasan dan Penetrasi Meloxicam dari Sistem NLC}

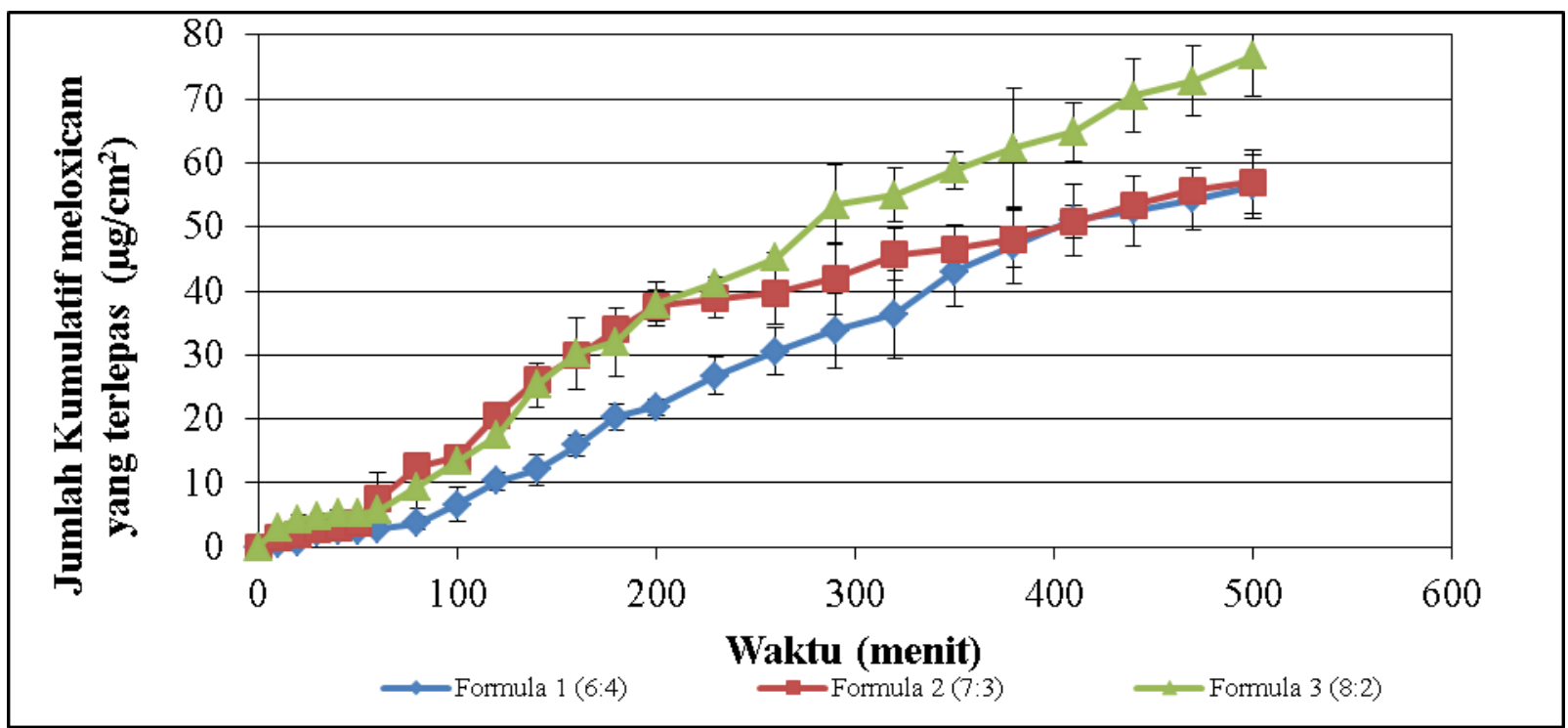

Gambar 2. Kurva hubungan antara waktu (menit) vs jumlah kumulatif \pm SD $\left(\mu \mathrm{g} / \mathrm{cm}^{2}\right)$ meloxicam yang dilepaskan dari sistem NLC formula 1, formula 2, dan formula 3. Data merupakan rerata dari tiga kali replikasi $\pm \mathrm{SD}$ 
Tabel 6 Harga fluks pelepasan meloxicam $\left(\mu \mathrm{g} / \mathrm{cm}^{2} /\right.$ menit) yang dilepaskan dari sistem NLC meloxicam formula 1 , formula 2 , dan formula 3

\begin{tabular}{|c|c|c|c|c|}
\hline \multirow{2}{*}{ Formula } & \multicolumn{3}{|c|}{ Fluks pelepasan meloxicam $\left(\mu \mathrm{g} / \mathrm{cm}^{2} /\right.$ menit $)$} & \multirow{2}{*}{ Rerata \pm SD } \\
\hline & Replikasi I & Replikasi II & Replikasi III & \\
\hline $1(6: 4)$ & 0,144 & 0,135 & 0,116 & $0,132 \pm 0,014$ \\
\hline $2(7: 3)$ & 0,098 & 0,106 & 0,091 & $0,098 \pm 0,008$ \\
\hline $3(8: 2)$ & 0,160 & 0,170 & 0,139 & $0,156 \pm 0,016$ \\
\hline
\end{tabular}

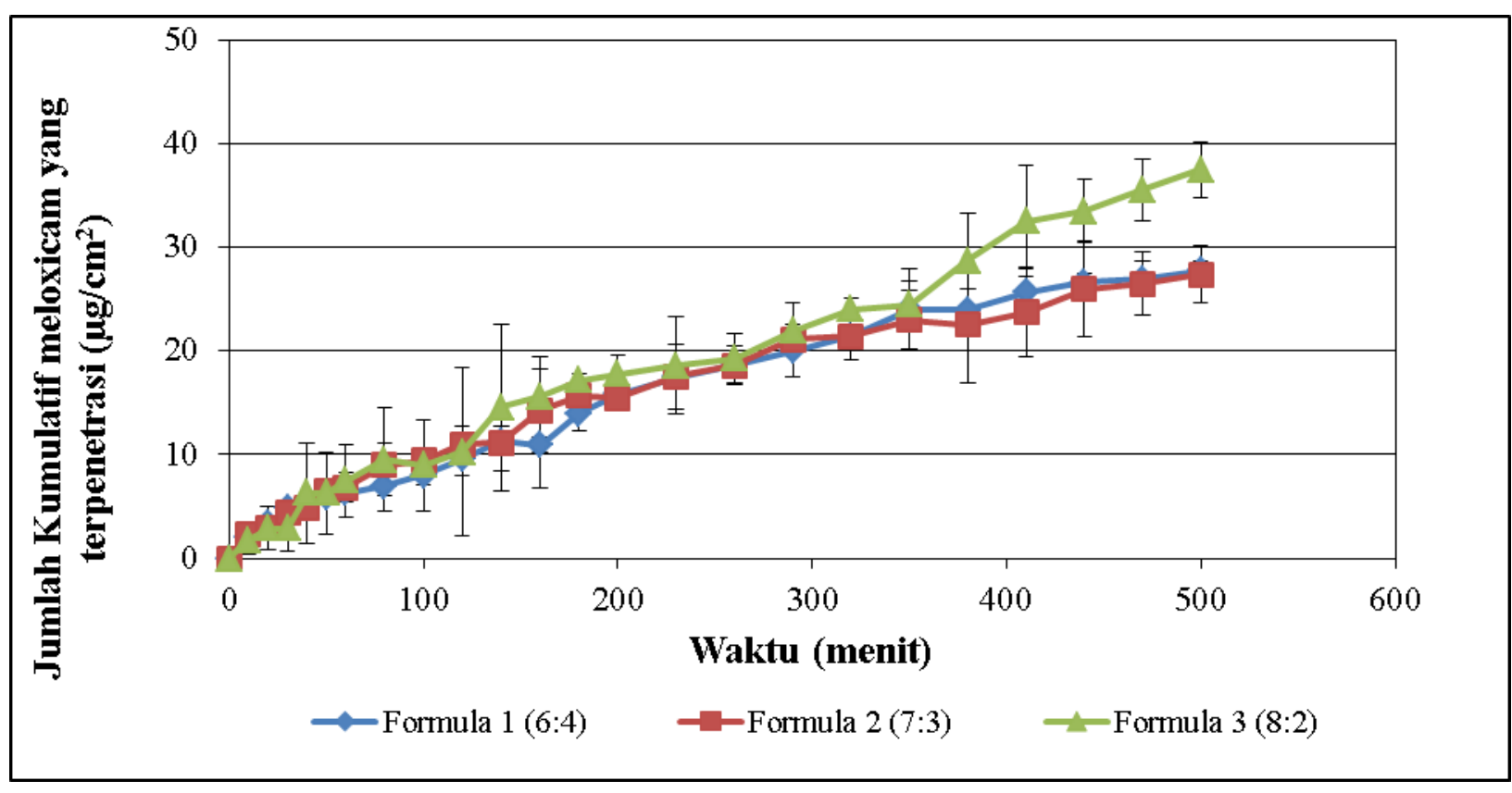

Gambar 3. Kurva hubungan antara waktu (menit) vs jumlah kumulatif \pm SD $\left(\mu \mathrm{g} / \mathrm{cm}^{2}\right)$ meloxicam yang terpenetrasi dari sistem NLC meloxicam formula 1, formula 2, dan formula 3. Data merupakan rerata dari tiga kali replikasi \pm SD

Tabel 7. Harga fluks penetrasi meloxicam $\left(\mu \mathrm{g} / \mathrm{cm}^{2} / \mathrm{menit}\right)$ yang terpenetrasi dari sistem NLC meloxicam formula 1, formula 2 , dan formula 3

\begin{tabular}{|c|c|c|c|c|}
\hline \multirow{2}{*}{ Formula } & \multicolumn{3}{|c|}{ Fluks penetrasi meloxicam $\left(\mu \mathrm{g} / \mathrm{cm}^{2} /\right.$ menit $)$} & \multirow{2}{*}{ Rerata \pm SD } \\
\hline & Replikasi I & Replikasi II & Replikasi III & \\
\hline $1(6: 4)$ & 0,053 & 0,055 & 0,053 & $0,054 \pm 0,001$ \\
\hline $2(7: 3)$ & 0,054 & 0,055 & 0,056 & $0,055 \pm 0,001$ \\
\hline $3(8: 2)$ & 0,086 & 0,067 & 0,058 & $0,070 \pm 0,014$ \\
\hline
\end{tabular}

Uji pelepasan dan penetrasi dilakukan dengan alat sel difusi Franz. Sel difusi Franz terbagi atas dua kompartemen, yaitu kompartemen donor dan kompartemen reseptor. Membran yang digunakan untuk uji pelepasan adalah membran selofan. Kondisi uji pelepasan dibuat sama, yakni pada suhu $32^{\circ} \mathrm{C}$. Pengambilan sampel disamakan untuk setiap pengujian. Cuplikan diamati serapannya menggunakan spektrofotometer UV pada panjang gelombang maksimum meloxicam 362 $\mathrm{nm}$. Kadar yang terukur dikoreksi dengan 
persamaan Wurster. Setelah itu, dibuat kurva hubungan antara jumlah kumulatif meloxicam yang terlepas terhadap waktu. Nilai fluks pada formula $1(6: 4)$, formula 2 (7:3), dan formula $3(8: 2)$ berturut-turut sebesar 0,132 $\pm 0,014 ; 0,098 \pm 0,008$; dan $0,156 \pm 0,016$. Berdasarkan hasil analisa statistika ANOVA one way pada uji pelepasan meloxicam dalam sistem NLC, diperoleh nilai p value (sig) sebesar 0,005 lebih kecil dari pada $\mathrm{p}$ tabel $(0,05)$. Hal ini menunjukkan bahwa ada perbedaan bermakna antara fluks pelepasan meloxicam formula $1(6: 4)$, formula 2 (7:3), dan fomula 3 (8:2). Untuk mengetahui formula mana yang berbeda maka analisis dilanjutkan dengan uji perbandingan berganda. Pada SPSS menggunakan Post Hoc Multiple Compararisons. Uji perbandingan menghasilkan $\mathrm{p}$ value lebih kecil dari $\alpha=0,05$ pada formula 2 dan formula 3 , sehingga dapat disimpulkan bahwa terdapat perbedaan fluks pelepasan antara formula 2 dan formula 3.

Beberapa faktor yang mempengaruhi pelepasan obat antara lain: viskositas dan ikatan kimia bahan aktif dengan pembawanya. Sistem NLC meloxicam formula 3 memiliki nilai fluks pelepasan lebih besar dari formula 1 dan formula 2, dalam hal ini apabila dikaitkan dengan efisiensi penjebakan meloxicam dalam sistem NLC meloxicam formula 3 juga memiliki \% penjebakan yang lebih besar dibandingkan formula 1 dan formula 2. Semakin besar penjebakan maka akan gradien konsentrasi dalam sistem akan meningkat, sehingga dorongan untuk terlepas akan semakin besar, sedangkan obat yang terlepas adalah obat yang tidak terjebak, meskipun dalam formula 3 jumlah obat yang tidak terjebak kecil akan tetapi dengan adanya dorongan yang besar menyebabkan jumlah pelepasan formula 3 lebih besar dibandingkan formula 1 dan formula 2.

Penetrasi perkutan adalah suatu sistem penghantaran suatu bahan melalui kulit dari luar tubuh ke dalam aliran darah. Bagian terluar dari kulit yang menentukan proses penetrasi adalah stratum corneum. Stratum corneum merupakan lapisan epidermis yang paling luar. Proses penetrasi terjadi secara difusi pasif. Efektifitas terapi dipengaruhi tiga komponen yaitu obat, pembawa, dan kulit. Proses pencapaian efek farmakologi sediaan perkutan meliputi tahap pelepasan obat dari pembawa, penetrasi melalui barrier kulit, dan aktivitas farmakologi. Cara yang dapat digunakan untuk meningkatkan daya absorpsi menembus kulit dan bercampur dengan sistem barrier (stratum corneum) ialah dengan adanya penambahkan enhancer. Pada formula sistem NLC meloxicam dipilih Tween-80 sebagai surfaktan, selain sebagai surfaktan Tween-80 digunakan sebagai enhancer karena dapat melarutkan lipid pada stratum corneum (Trommer \& Neubert, 2006).

Pada penelitian ini, uji penetrasi menggunakan membran kulit tikus. Kulit tikus yang digunakan merupakan galur wirstar jantan yang telah dicukur bulunya. Kulit tikus digunakan dalam uji penetrasi ini karena kulit tikus sebagai membran mudah diperoleh dan telah dilaporkan sebelumnya bahwa permeabilitasnya mirip dengan kulit manusia. Pencukuran bulu pada kulit yang digunakan dimaksudkan agar tidak mengganggu penetrasi meloxicam melewati membran (Walters, 2007). Pencukuran dilakukan dengan hati-hati agar tidak melukai membran. Kulit dipasang secara hati-hati dalam sel difusi Franz dan diusahakan tidak ada udara yang terperangkap karena dapat menghalangi kontak antara membran dan cairan penerima sehingga penetrasi dapat terhambat (Walters, 2007).

Dapar fosfat $\mathrm{pH} \quad 7,4$ dipilih sebagai cairan reseptor karena simulasi kondisi $\mathrm{pH}$ cairan fisiologis manusia adalah $\mathrm{pH} 7,4$. Sistem difusi diatur suhu sesuai suhu tubuh, yaitu $\pm 37^{\circ} \mathrm{C}$ dengan mengalirkan larutan dapar disekeliling 
kompartemen reseptor. Suhu kompartemen harus dijaga karena perubahan suhu dapat mengakibatkan perubahan laju difusi meloxicam menembus membran (Sinko, 2006). Kompartemen reseptor diaduk dengan menggunakan magnetic stirrer pada kecepatan 100 rpm untuk menjaga cairan kompartemen tetap homogen. Penggunaan kecepatan yang lebih tinggi dapat menyebabkan timbulnya gelembung gas diantara membran dan cairan kompartemen reseptor (Christina, 2010).

Uji penetrasi secara in vitro memiliki dua parameter utama yaitu jumlah kumulatif zat aktif yang terpenetrasi dan laju penetrasi (fluks). Dari hasil jumlah yang terpenetrasi tersebut dapat dihitung presentase meloxicam yang terpenetrasi. Fluks dapat dihitung dengan menarik garis linier dari kurva jumlah kumulatif zat aktif terpenetrasi terhadap waktu sehingga didapatkan persamaan $\mathrm{y}=\mathrm{bx}+\mathrm{a}$ atau kemiringan yang menyatakan nilai fluks.

Data uji penetrasi sistem NLC meloxicam menunjukkan harga fluks formula 1 (6:4), formula (7:3), dan formula $3 \quad(8: 2)$ secara berturut-turut sebesar $0,054 \pm 0,01 ; 0,055 \pm 0,01 ; 0,070$ \pm 0,01. Berdasarkan hasil analisa statistika ANOVA one way pada uji penetrasi meloxicam dalam sistem NLC, diperoleh nilai $\mathrm{p}$ value (sig) sebesar 0,091 lebih besar dari pada $\mathrm{p}$ tabel $(0,05)$. Hal ini menunjukkan bahwa tidak ada perbedaan bermakna antara fluks penetrasi meloxicam dalam sistem NLC dengan menggunakan perbandingan lipid yang berbeda yaitu 6:4, 7:3 dan 8:2.

\section{KESIMPULAN}

1. Penggunaan lipid Monostearin dan Miglyol 808 pada perbandingan 6:4, 7:3, dan 8:2 menunjukkan bahwa tidak ada perbedaan bermakna pada karakteristik $\mathrm{pH}$ dan ukuran partikel, sedangkan pada efisiensi penjebakan dan viskositas terjadi peningkatan bermakna dengan meningkatnya perbandingan lipid.

2. Ada perbedaan bermakna antara fluks pelepasan meloxicam sistem NLC dengan menggunakan lipid Monostearin dan Miglyol 808 pada perbandingan $6: 4,7: 3$, dan $8: 2$, sedangkan untuk fluks penetrasi tidak terdapat perbedaan bermakna.

3. Sistem NLC meloxicam menggunakan lipid Monostearin dan Miglyol 808 pada perbandingan 8:2 adalah kombinasi yang paling optimal, dikarenakan menunjukkan karakteristik fisikokimia sesuai dengan kriteria sistem NLC meloxicam, nilai fluks pelepasan yang besar.

\section{DAFTAR PUSTAKA}

1. Anggreini, Y., Hendradi, E., Purwanti, T., 2012. Karakteristik Sediaan dan Pelepasan Natrium Diclofenak dalam Sistem Niosom dengan Basis Gel Carbomer 940. PharmaScientia 1: 6

2. Bertram, G., and Katzung, MD., 2009. Basic and Clinical Pharmacology, $11^{\text {th }}$ Ed, United States: McGraw-Hill Companies Inc, pp 817-819.

3. Bhaskar, K., Anbu, J., Ravichandiran, V., Venkateswarlu, V., and Rao, Y.M., 2009. Lipid Nanoparticles for Transdermal Delivery of Flurbiprofen: Formulation, in vitro, ex vivo and in vivo Studies. BioMed Cent 8: 254-258.

4. Christina, 2010. Pengaruh Mentol, Etanol, dan Propilen Glikol Terhadap Profil Penetrasi Perkutan Glukosamin Secara in Vitro Menggunakan Sel Difusi Franz. Skripsi, Universitas Indonesia, Indonesia.

5. Cirri, M., Bragagni, M., Mennini, P., 2012. Development of a New Delivery System Consisting "Drug-in Cyclodextrin-in Nanostructured Lipid Carriers" for Ketoprofen Topical 
Delivery. Eur $J$ of Pharm and Biopharm 80(1): 46-53.

6. El-Megrab, N., El-Nahas, H., Gehan., F., 2006. Formulation and Evaluation of Meloxicam Gels for Topical Administration. Egypt J of Pharm 14: 3-4.

7. Godin, B., and Touitou, E., 2007. Transdermal Skin Delivery: Prediction for Human Fron in Vivo, Ex Vivo and Animals Model. $A d v$ Drug Deliv Rev 59: 1152-1161.

8. Han, F., Li, Sanming, Yin, Ran, Liu, Hongzhuo, Xu, Lu, 2008. Effect of Surfactants on the Formation and Characterization of a new type of Colloidal Drug Delivery System Nanostructured Lipid Carriers. Inter J of Pharm 315: 210-216.

9. Han, F., Yin, R., Che, X., Yuan, J., Cui, Y., Yin, H., Li, S., 2008. Nanostructured Lipid Carriers (NLC) Based Topical Gel of Flurbiprofen: Design, Characterization and in Vivo Evaluation. Inter $J$ of Pharm 439: 349- 357.

10. Hu, F.Q., Jiang, S.P., Du, Y.Z., Yuan, H., Zeng, S., 2006. Preparation and Characteristics of Monostearin Nanostructured Lipid Carriers. Inter J of Pharm 314: 83-89.

11. Joshi, M., and Patravale, V., 2008. Nanostructured Lipid Carrier (NLC) Based Gel of Celecoxib. Inter $J$ of Pharm 346: 124-132.

12. Khurana, S., Jain, N.K., Bedi, P.M.S., 2013. Development and Characterization of a Novel Controlled Release Drug Delivery System Based on Nanostructured Lipid Carriers Gel for Meloxicam. Life Sci 93: 763-772.

13. Muller, A.Z., Schwarz, C., Menhert, W., 1998. Solid Lipid Nanoparticles (SLN) for Controlled Drug DeliveryDrug Release and Release Mechanism. $J$ of Pharm and Biopharm 45: 149-155.

14. Muller, R.H., Mader, K., Gohla, S., 2002. Solid Lipid Nanoparticles for
Controlled Drug Delivery a Review of the State of the Art. Eur $J$ of Pharm and Biopharm 50: 161-177.

15. Muller, R.H., Radike, M., Wissing, S.A., 2007. Solid Lipid Nanoparticles (SLN) and Nanostructured Lipid Carrier (NLC) in Cosmetic and Dematological Preparations. Adv Drug Deliv Rev 1: 131-155.

16. Pardeike, J., Hommos, A., Muller, R.H., 2009. Lipid Nanoparticles (SLN and NLCs) in Cosmetic and Pharmaceutical Dermal Product. Inter J of Pharm 336: 170-184.

17. Phatak, A., and Chaudhari, P., 2013. Development and Evaluation of Nanostructured Lipid Carrier (NLC) Based Topical Delivery of an Antiinflamatory Drug. $J$ of Pharm Res 7(8): 677-685.

18. Rowe, R.C., Sheykey, J.C., Quinn, M., 2009. Handbook of Pharmaceutical Excipient. $6^{\text {th }}$ Ed. USA: Pharmaceutical Press.

19. Sinko, Patrick, 2011. Physical Pharmacy and Pharmaceutical Science. $6^{\text {th }}$ Ed. Cina: Lippincot Williams \& Wilkins, pp 355-367, 469-473.

20. Sivaramakrishnan, R., Nakamura, C., Mehnert, W., Korting, H.C., Kramer, K.D., Schafer-Korting, M., 2004. Glucocorticoid Entrapment Into Lipid Carriers Characterisation by Parelectric Spectroscopy and Influence on Dermal Uptake. $J$ of Cont Rel 97: 493-502.

21. Souto, E.B., and Muller, R.H., 2007. Lipid Nanoparticles (Solid lipid Nanoparticles and Nanostructured Lipid Carriers) for Cosmetic, Dermal, and Transdermal Applications. Drug and Pharm Sci 166: 213-232.

22. Souto, E.B., Wisiing, S.A., Barbosa, C.M., Muller, R.H., 2004. Development of a Controlled Release Formulation Based on SLN and NLC for Topical Clotrimazole delivery. Inter J of Pharm 278: 71-77. 
23. Stecova, J., Mehnert, W., Blaschke, T., Kleuser, B., Sivaramakrishnan, R., Zouboulis, C., Seltmann, H., Korting, H.C., Kramer, K.D., Schafer-Korting, M., 2007. Cyproterone Acetate Loading to Lipid Nanoparticles for Topical Acne Treatment. Pharm Res 24: 5.

24. Trommer, H., and Neubert, R.H.H., 2006. Overcoming the Stratum Corneum the Modulation of Skin Penetration. German: Martin Luther University, pp 106-121.

25. Walters, K.A., 2007. Dermatological and Transdermal Formulation (Drugs and Pharmaceutical Sciences). New York: Marcel Dekker Inc, pp 1-4.

26. Westesen, K., Siekmann, B., 1997. Investigation of the Gel Formation of Phospholipid Stabilized Solid Lipid Nanoparticles. Inter J of Pharm 151: 35-45.

27. Yuan, H., Wang L.L, Du Y.Z, You, J., Hu, F.Q, Zeng, S., 2007. Preparation and Characteristics of Nanostructured Lipid Carriers for Control Releasing Progesterone by Melt Emulsification. Inter J of Pharm 60(2): 174-179. 